\title{
New governance of protected areas: regional nature parks in Switzerland
}

\author{
Marco Pütz, Lena Gubler \& Yasmine Willi
}

Keywords: environmental governance, regional governance, protected area, regional development, regional nature park, Switzerland

\section{Abstract}

Governance of protected areas is a rapidly growing research field as new actors rather than governments play crucial roles in decision-making processes, and new forms and mechanisms of decision-making complement existing regulations. However, little is known about the key characteristics of new forms of protected area governance and how they differ from older governance concepts. In this paper we use the example of newly established regional nature parks in Switzerland to address similarities and differences between new and older concepts of governance, and to address similarities and differences between different regional practices of new protected area governance across Switzerland. Drawing on different empirical sources and methods, our findings reveal diverse governance practices of regional nature parks in Switzerland. We identified three forms of park organization: (i) organized as association; (ii) parks affiliated to single municipalities; and (iii) parks associated with a regional development bodies. Different governance practices also result from different forms of regional embeddedness between top-down and bottom-up approaches and the related tensions.

\section{Introduction}

In recent decades the number of protected areas has increased significantly around the world. At the same time the governance of protected areas (PAs) has also changed considerably. Traditionally, PAs were run by the state and managed by government employees, while nowadays they are increasingly established and managed by local communities, indigenous people, ecotourism organizations, non-profit trusts or commercial companies. In response the International Union for Conservation of Nature (IUCN) introduced four governance types, which can be observed globally, based on who has the authority and responsibility and can be held accountable for the key decisions in PAs: governance by government, shared governance, private governance, and governance by indigenous peoples and local communities (Borrini-Feyerabend et al. 2013). In practice the governance of PAs can be quite diverse and may include multiple governance types and subtypes.

Both the growing number of PAs and the shift in governance modes can be observed in Switzerland. In recent years Switzerland has experienced a park creation boom (Weissen 2009), a trend which can also be observed in other countries across Europe (Hammer et al. 2016). Based on the revised Federal Act for the Protection of Nature and Cultural Heritage (NCHA), 15 new PAs have been established since 2008 (March 2016): 14 regional nature parks and one nature discovery park. Four more planned park projects, labelled candidates, await their approval and implementation: two new national parks and two new regional nature parks (www.paerke.ch). Common to these PAs is their "governance structure based upon cooperation between the relevant local and regional actors" (Hammer \& Siegrist 2016, 94) and that a park is established in a bottom- up process. We refer to the shift in the way PAs in Switzerland are managed and governed as new governance of PAs for four reasons (BAFU 2015a; Gerber \& Knoepfel 2008; Weissen 2009):

- New legislative framework setting new rules and incentives for PAs in Switzerland;

new decision-making processes demanding a participatory process involving local initiatives and approval from local municipalities in referenda to establish a park;

new actor compositions arising from the PAs' increased reliance on ideas and commitment from private business, e.g. agriculture, tourism and civil society; and

new understanding of PAs as tools for regional development (Mose \& Weixlbaumer 2006), often implemented as tourism development, represented especially by regional nature parks.

Taking the new governance of PAs as one basic assumption and starting point of the article, we focus on established regional nature parks in Switzerland. First, the paper identifies the characteristics of the new governance of PAs and distinguishes new from older modes of governance. Second, the paper examines the specific regional practices of the new governance of PAs. This leads to two research questions:

1. What characterizes the new governance of PAs and in what respect does the new governance complement or substitute older governance concepts?

2. How do the regional practices of the new governance of PAs differ between Switzerland's regional nature parks?

In relation to the second research question we base our article on a second basic assumption. We assume that regional practices of the new governance of PAs 


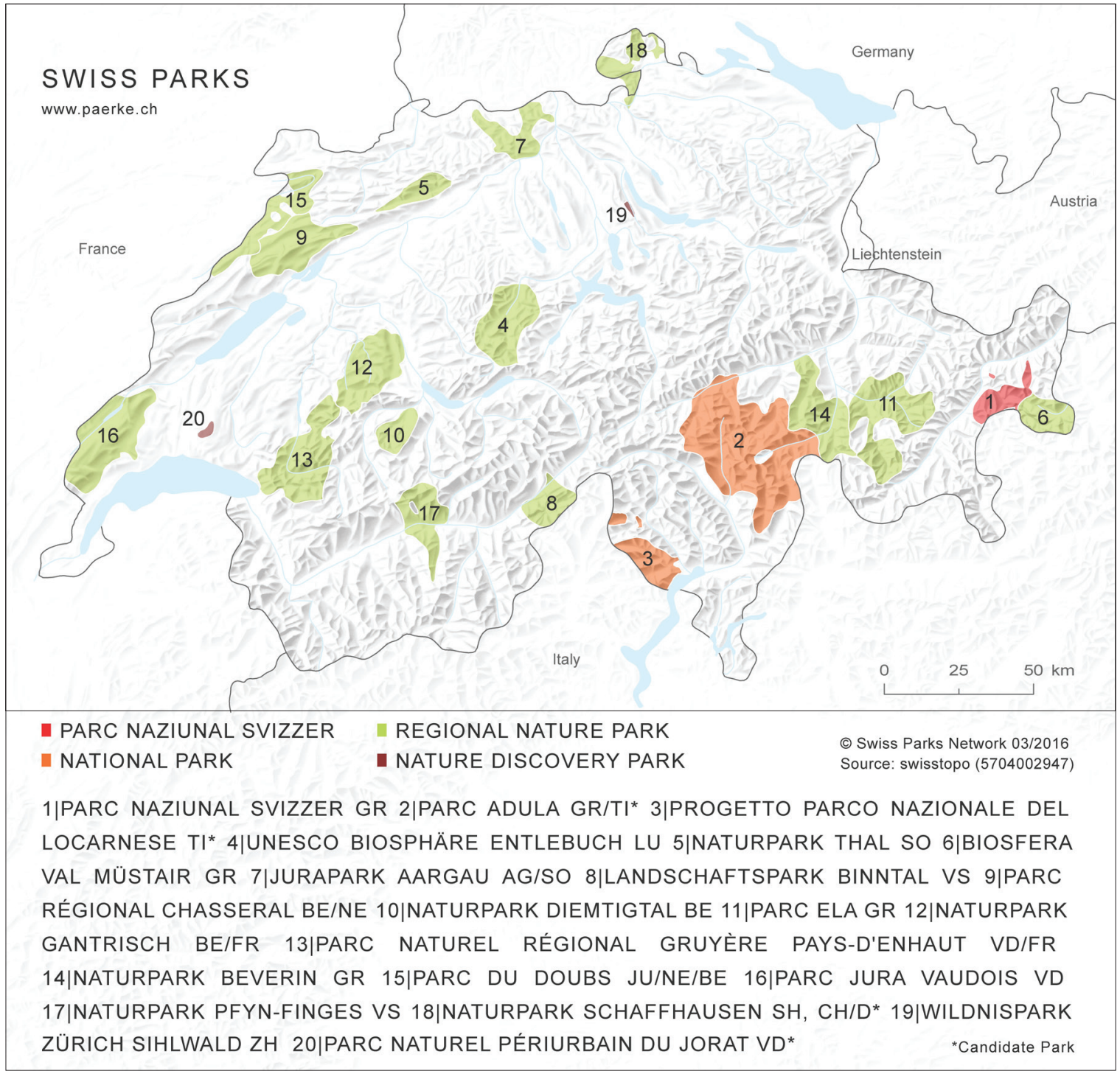

Figure 1 - Parks and park candidates in Switzerland (as of March 2016).

differ between regions. This paper adopts a practicedbased (Arts et al. 2014) approach to understand the new governance of PAs and to empirically analyse Switzerland's regional nature parks. Focusing on the actual practices of coordination, management and decision-making is highly applicable in order to unpack the relations between different levels of government and different actors (Pütz \& Job 2016).

\section{Governance of PAs: state of the art}

Conceptually this paper contributes to the debate on the governance of PAs which has attracted increasing scholarly interest (Armitage et al. 2012; Dearden et al. 2005; Eagles 2014, 2009). Governance is globally recognized as a key issue of PA research to better understand emerging governance arrangements and to improve the effectiveness of PA governance. The increased scholarly interest in PA governance is shared by practice and international organizations, such as the IUCN, that consider governance crucial for effective and equitable conservation (Borrini-Feyerabend et al. 2013). According to the catalogue of comparative research topics on parks and PAs in Switzerland, park governance is one of seven core research topics and is located at the intersection of societal, economic and ecological issues (Wallner 2012). Park governance is considered an interesting and relevant research topic because a park represents a new actor in an established but complex multi-level environment of local and regional institutions and national regulations. Also, the local population expects much from the regional nature park, despite the fact that park administrators have no official mandate and do not form an administrative unit.

A common feature of current empirical research on the governance of PAs is the study of single regional case studies. A great variety of research can be found on the question how to refer to governance conceptually. In that respect a lot of PA research focuses on just one specific element of governance. Basurto (2013), for instance, studies the emergence and 
endurance of autonomy among local institutions for biodiversity conservation in Costa Rica by conceptually linking multi-level governance to common-pool resource theory. Novellie et al. (2016) focus on the role of environmental legislation and national law for adaptive governance in South Africa's national parks. Buono et al. (2012) investigate participatory practices, focusing on local community involvement in Italian national park management.

We observe three bodies of PA governance research. First, many scholars focus on actors or stakeholders and their different, sometimes conflicting, interests and roles, e. g.: stakeholder support or resistance to conservation in Mexican biosphere reserves (Brenner \& Job 2011), negotiation of indigenous rights and conservation interests in a Colombian national park (Premauer \& Berkes 2015), the policy and practice of partnerships in a national park in England (Austin et al. 2016), or power relations between PAs and local communities in nature reserves in the Dominican Republic (Holmes 2013), to highlight just a few. Second, other scholars concentrate on the institutional and regulatory dimension of PA governance, e.g. interpretation and implementation of the EU Habitats and Birds Directives in the Netherlands (Beunen \& Van Assche 2013), co-existing public-private management bodies, including concessions in the Vietnamese park system (Ly \& Xiao 2016) or community-based conservation within the framework of weak state institutions in Tanzania (Robinson \& Makupa 2015). A third body of work is looking into principles and mechanisms of good governance. Understanding, establishing and maintaining good practices and good governance, i. e. normative statements about how to govern PAs, is critical for the future effectiveness and acceptability of PAs (Lockwood 2010). It is obvious that good governance criteria differ greatly between developed countries and countries from the global south. Interestingly, good PA governance principles, such as legitimacy, transparency, accountability, inclusiveness, fairness, connectivity and resilience, can also be found in other forms of environmental governance.

\section{Swiss parks of national importance}

The revision of the Federal Act NCHA, which came into force in December 2007, provides the legal basis for the establishment and operation of parks of national importance (PNIs, BAFU 2015a). Before, only one Swiss national park had been in existence since 1914 based on a special National Park Act designated for its establishment. Swiss PNIs are characterized by their scenic beauty, rich biodiversity and valuable cultural heritage. The new parks contribute to different measures for maintaining natural assets in Switzerland, e.g. habitat inventories, nature reserves, protected zones, landscape inventories and the national biodiversity strategy. In addition to these ecological measures, PNIs present a new model for Swiss parks by providing opportunities for sustainable regional development, including added economic and social value. Swiss parks result from a basic democratic process; they are based on regional initiatives and have to be supported by a majority of citizens living inside the park perimeter.

The NCHA defines three park categories, which are specified in the Parks Ordinance (Schweizerischer Bundesrat 2007). National Parks have a core zone of at least $100 \mathrm{~km}^{2}$, plus a buffer zone. Visitors are allowed to access the core zone only on existing paths. The buffer zone is a cultural landscape including villages and agriculture, forestry and tourism. Regional Nature Parks represent a rich, intact cultural landscape including indigenous plants, wildlife, habitats and distinct local features. These park characteristics have to be maintained to create added value, e.g. ecotourism, regional products and environmental education. The UNESCO Biosphere Reserve (BR) Entlebuch is both UNESCO BR (established 2001, the only Swiss BR by UNESCO's Seville criteria) and Regional Nature Park (established in 2008). The case of Biosfera Val Müstair is more complex: although Biosfera Val Müstair received the UNESCO label in 2010, the park on its own currently does not hold the UNESCO label after a negative popular vote in 2015. However, Biosfera Val Müstair is part of the newly named UNESCO BR Biosfera Engiadina Val Müstair, which encompasses the Biosfera Val Müstair plus the Swiss National Park and the municipality of Scuol. Nature Discovery Parks consist of core and transition zones and are located no further than $20 \mathrm{~km}$ from an urban area and are accessible by public transport. Wildnispark Zürich Sihlwald, close to the city of Zurich, is the only approved $\mathrm{Na}$ ture Discovery Park so far. Parc Naturel Périurbain Du Jorat is a candidate park and located close to Lausanne (see Figure 1).

Currently 15 parks are in operation who obtained the PNI label between 2008 and 2013. Four parks, including two new national park projects, are still in the establishment phase as candidates (see Figure 1).

To meet park requirements, an effective park authority and proficient management are essential. A park charter is required to set goals and measures to be achieved. If a park meets the requirements, the Federal Office for the Environment (FOEN) awards the label, Park of National importance, which is valid for 10 years. Products and services which are sold by businesses operating within the park perimeter can be awarded a park product label, certified by park authorities (BAFU 2013). For the programme period 2016-2019, the Federation offers CHF 67.9 million to the cantons as subsidiary support for PNIs (BAFU 2015b), while CHF 37.2 million are designated for regional nature parks. 


\section{Methods}

This study investigates ongoing transformations of governance structures and practices of PAs. Therefore this study is explorative and reports on work in progress. The empirical research draws on different data and mixed methods (document analysis, survey, expert interviews) and is in two parts:

First, a document analysis was carried out, the review of which focused on grey literature and documents provided by FOEN, the Swiss Parks Network and the parks themselves, including statutes or charters, annual reports and the annual accounts of all 14 examined parks. These documents were collected from websites or requested directly from the park management. The annual reports summarize the park's annual activities. They focus on the participation of residents and visitors and on the cooperation between the park management and other sectors in the region. No annual report could be obtained for the Biosfera Val Müstair. The annual accounts are part of the annual reports and provide the annual global budget, including the output of the parks. They list the different sources of park income: the proportional financial contribution of the federal and cantonal governments, the member contributions (primarily from the member municipalities) and the contributions from foundations or the regional economy. In addition, the sales of project-related goods and services (e.g. income from field trips, environmental education programmes, park memorabilia and printed media) offered by the park as well as the income from licensing the park product label for regionally produced goods can make up a fair share of a park's income. The annual accounts differ considerably in their level of detail. While eight of the annual accounts show the different sources of income and all the expense items separately, three simply summarize federal and cantonal funding, and the remaining three do not break down the different sources of income at all. The parks are usually organized as associations. Only two parks are directly associated with municipalities and therefore do not require charters and statutes. For the other parks the charters and statutes define the overall goals, which are regionally adapted. The statutes present the different organs and their function (strategic, performing or consultative). General information, such as the number of members, number of habitants within the park perimeter, surface area of the park and year of foundation, was collected from park websites and from the Swiss Parks Network.

Second, a short standardized survey of all the managing directors of the 14 parks was carried out by email in French and German in February 2016. Each park participated in the survey by providing answers to all questions. The survey aimed at investigating the influence of municipalities, cantons and the federation on the strategic orientation of parks, their embedded- ness within a region and the main sectors for collaboration. The answers were analysed by means of descriptive statistics and qualitative content analysis. In order to balance and validate the survey's results, two guided oral expert interviews were conducted with the presidents of the Swiss Parks Network and the Scientific Board of Park Research Switzerland. The two interviewees were also questioned about their views on the characteristics of the new governance of PAs, the different governance practices, the conditions and barriers of participation, and the future potential of the regional nature parks in Switzerland.

\section{Results}

\section{Key figures}

Swiss regional nature parks vary considerably in area size, number of inhabitants, number of municipalities and funding (see Table 1). This is due to different landscape, socio-economic and political conditions and trajectories and similar to most of the other nature parks in Europe. Landschaftspark. Binntal has the smallest area $\left(181 \mathrm{~km}^{2}\right)$ and number of inhabitants (1288). The largest area, however, does not correspond with the largest number of inhabitants. The largest park, Parc Ela, covers $548 \mathrm{~km}^{2}$, but only 5245 people live here. Naturpark Doubs, with an area of $531 \mathrm{~km}^{2}$, has the most inhabitants (59700). The number of municipalities also varies across the different parks, ranging from Naturpark Jura Vaudois with the most (30) to Biosfera Val Müstair and Naturpark Diemtigtal with the least (1). Furthermore, the parks also differ considerably in the number of their members, such as member municipalities, local companies, individuals and collective members (from 79 members in Parc Ela to 633 members in Naturpark Gruyère Pays-d'Enhaut).

Park funding differs considerably in terms of volume and sources of budget. The annual budget of 2014 ranges from CHF 620000 (Biosfera Val Müstair) to CHF 2830000 (UNESCO Biosphäre Entlebuch), depending on the park's activities, the territorial dimensions, the performed regional supporting function and the representing tasks. The park budget is composed of three income sources (see Table 1): a) payments from the federation and cantons; b) income from membership fees (e.g. municipalities, regional businesses, private individuals) and private sponsoring; and c) income generated by the park, such as licensing the park product label to goods and services sold by businesses operating within the park perimeter and from selling park products and services.

Generally, FOEN provides the main financial source for most of the parks, between $31.8 \%$ and $46 \%$ of the annual budget, except for two cases. For the UNESCO Biosphäre Entlebuch, federal financial support is only $21 \%$. Here the main source of income $(59 \%)$ comes from the park's own activities, such as selling goods and services and distributing the product label, as well as from sponsoring. Similarly, Nature 
Table 1 - Key figures of Swiss regional nature parks. Sources: Annual reports of regional nature parks 2014, Swiss Parks Network (http:/ / www.paerke.ch).

\begin{tabular}{|c|c|c|c|c|c|c|c|c|c|c|c|c|c|}
\hline Regional Nature Park & General & park $f$ & acts & & & & & Financial fa & acts & & & & \\
\hline & 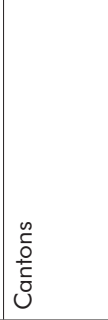 & 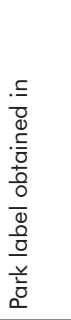 & 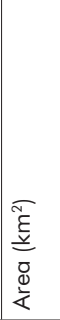 & 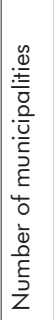 & 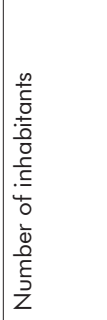 & 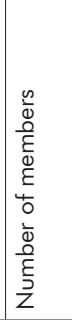 & 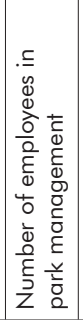 & 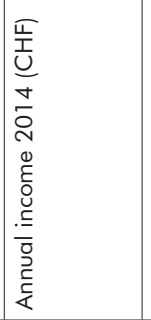 & 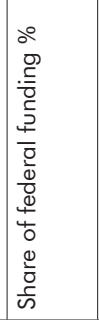 & 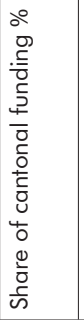 & 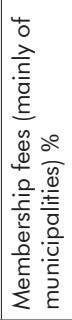 & 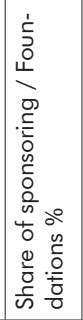 & 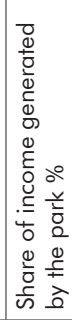 \\
\hline Biosfera Val Müstair & GR & 2011 & 199 & 1 & 1550 & & 3 & 619918 & & 71.94 & 21.8 & & 6.31 \\
\hline Jurapark Aargau & $A G$ & 2012 & 244 & 28 & 37000 & 444 & 8 & 1160000 & 37.8 & 19.8 & 18.9 & & 23.5 \\
\hline Landschaftspark Binntal & VS & 2012 & 181 & 6 & 1288 & 310 & 8 & 933235 & & & & 85.6 & 14.4 \\
\hline Naturpark Beverin & GR & 2013 & 373 & 11 & 2483 & n.s. & 6 & 965000 & 32.6 & 22.8 & 5.9 & 40.1 & 1.8 \\
\hline Naturpark Chasseral & $\mathrm{NE} / \mathrm{BE}$ & 2012 & 387 & 21 & 38000 & 311 & 7 & 1804749 & 31.8 & 29.4 & 10.9 & 15.9 & 12.0 \\
\hline Naturpark Diemtigtal & BE & 2011 & 135 & 1 & 2140 & 163 & 8 & 1120000 & n.s. & & 5.4 & & \\
\hline Naturpark Doubs & $\begin{array}{l}\mathrm{JU} / \mathrm{NE} / \\
\mathrm{BE}\end{array}$ & 2013 & 294 & 16 & 59700 & 147 & 6 & 710292 & & 69.0 & 10.3 & 18.7 & 2.0 \\
\hline Naturpark Gantrisch & $\mathrm{BE} / \mathrm{FR}$ & 2012 & 404 & 28 & 43500 & 372 & 11 & 1909307 & 33.1 & 31.0 & 11.5 & 2.6 & 21.7 \\
\hline Naturpark Gruyère Pays-d'Enhaut & FR/VD & 2012 & 503 & 13 & 12500 & 633 & 8 & 987900 & 40.5 & 27.2 & 14.9 & & 17.4 \\
\hline Naturpark Jura voudois & VD & 2013 & 531 & 30 & 32000 & 202 & 8 & 1191023 & 35.3 & 19.1 & 10.9 & 15.8 & 19.0 \\
\hline Naturpark Pfyn-Finges & VS & 2013 & 276 & 12 & 27120 & 84 & 12 & 1855614 & n.s. & & & & \\
\hline Naturpark Thal & so & 2010 & 139 & 9 & 14400 & n.s. & 6 & 995061 & n.s. & & & & \\
\hline Park Ela & GR & 2012 & 548 & 8 & 5245 & 79 & 7 & 1181340 & 46.3 & 29.6 & 7.6 & 16.2 & 0.2 \\
\hline UNESCO Biosphäre Entlebuch & LU & 2008 & 394 & 7 & 17000 & 350 & 11 & 2860143 & 21.0 & 7.0 & 11.8 & & 59.0 \\
\hline
\end{tabular}

Park Beverin receives its largest share of income from private sponsoring and foundations, which made up $40 \%$ of the park income in 2014 . The share of cantonal financial support varies considerably, ranging from $7 \%$ to $31 \%$ of the annual park incomes. The range of financial support for the parks from both FOEN and cantons is due to the different services parks provide. These services and the related funding are negotiated and defined by contract for each park. The financial contribution from park members (e. g. municipalities, businesses or private persons) cover around $10 \%$ of park incomes, with the lowest share of $5.4 \%$ in the Regional Nature Park Diemtigtal and the highest share of $21.8 \%$ in the Biosfera Val Müstair.

\section{Park organization}

Regional nature parks in Switzerland are organized in three different ways:

1. as an association;

2. affiliated to single municipalities; and

3. associated with a regional development agency.

The majority of the parks are organized as associations following the standard structure made up of members, board, executive management, revision organ and working groups. The park boards consist of representatives of the member municipalities and represent the majority of the board. Other interests, such as representatives from agriculture, the economy, forestry, tourism, environmental organizations, the church or unions, can also be represented on the board. Representatives from the cantonal government are rarely on the board. In some parks so-called Friends of the Regional Nature Park or permanent working groups are also on the board.

Parks affiliated to single municipalities are Biosfera Val Müstair and Regional Nature Park Diemtigtal. The municipality of Val Müstair resulted from a merger of six municipalities in 2009. The park perimeter of the Biosfera Val Müstair is identical to the municipality area. In the case of the Nature Park Diemtigtal, a small part of another municipality is inside the park perimeter and is involved in the park's decision-making processes.

Parks associated with a regional development agency are Naturpark Thal and UNESCO Biosphäre Entlebuch. Naturpark Thal is incorporated into the regional development agency, Region Thal, which is responsible for regional economic, social and environmental planning and development. UNESCO Biosphäre Entlebuch is run by the association of local authorities (Gemeindeverband of seven municipalities) as an organizing institution.

Beside this institutionalized structure, parks include different participative panels of two basic models. First, formal participation is enabled through: a) consultative councils, which are open to all interested individuals, and deal with strategic discussions, park activities and general questions; b) park internal referenda and initiatives launched by the affected population; and c) advisory committees, convoked by the board. Second, issue-specific participation is enabled through temporary working groups in collaboration with local stakeholders or advisory committees' con- 
sulting working groups. While all the park associations have permanent or temporary working groups or issue-specific commissions (or at least the possibility to constitute them in case of need), only six parks have established a formal participative panel. However, the main channel of participation leads from the local municipality assemblies via their representatives to the regional nature park's boards.

Parks in-between top-down, bottom-up and sectoral influences

The survey of the parks' managing directors revealed that the parks' strategic orientation is influenced by different actors (see Figure 2). The park board and park management are considered the most influential organs, as they were mentioned in $28 \%$ and $26 \%$ of all answers. As the park board is to a large extent made up of representatives from the park municipalities, the municipalities themselves play an important role in directing the park strategies. Not surprisingly, municipalities were ranked high among the most influential actors on park strategies, as they were additionally mentioned in 13\% of all answers. Almost as important as the board is the park management, which is not necessarily composed of park members, but of employed professionals with appropriate profiles and qualifications. These findings hint at the regional embeddedness of parks, the bottom-up establishment phase of parks, and the willingness of municipalities to run their parks as autonomously and self-determinedly as possible. This finding might seem contradictory at first glance, as parks are financially dependent on federal and cantonal resources (in most cases). However, this finding has been confirmed by the two experts interviewed after the survey. Both experts acknowledged the power of municipalities in influencing the strategic orientation of the parks and stressed the importance of the bottom-up principle on which parks are based. This finding is also in line with Swiss federalism and the practice of multi-level governance, with legislation and funding provided at national level and implementation and operation at regional and local levels. More interesting is the fact that park municipalities function so naturally at regional level.

FOEN provides the main financial resources as well as legal and other supporting frameworks. However, the importance of this federal framework for the strategic orientation of the individual park is assessed differently by the park management. Whereas Nature Park Diemtigtal (municipality of Diemtigen) sees FOEN as the main driver, Val Müstair, the other park associated with a political municipality, stresses the importance of the park committee and park management. The participative panels are also mentioned several times in terms of strategic influence but are never ranked first.

In contrast to the strong influence of municipalities and, to a lesser degree, of FOEN, the role of the cantonal governments has been regarded as less

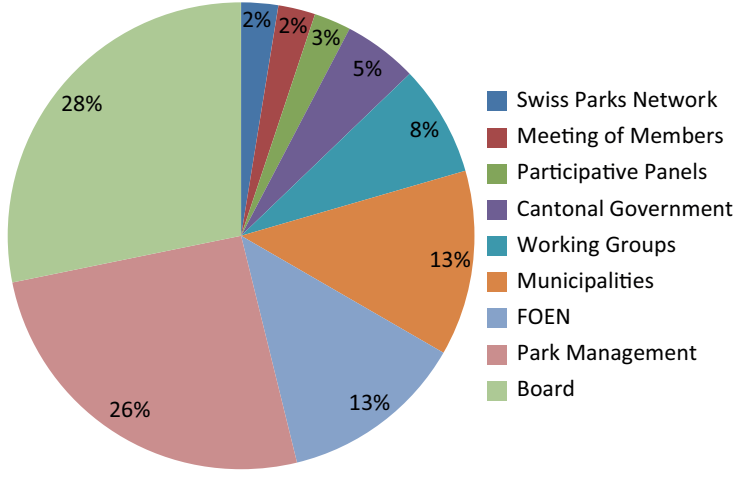

Figure 2 - Actors with main influences on parks' strategic orientation, according to a survey of park directors (multiple answers; authors' own figure based on survey results).

prominent by the managing directors. Likewise, the results from the expert interviews confirm this finding, but also indicate that cantons engage differently in park matters. More hierarchically organized cantons tend to be more influential on park strategies. Indeed, Parc Jura Voudois lists the canton in the first place as having the biggest influence on the park's strategic orientation.

The managing directors clearly identified agriculture and tourism as the two main sectors of collaboration. This is interesting in so far as collaboration with these two (and other) sectors is almost never mentioned in the statutes of the parks. Only Parc Ela refers to agriculture and tourism as part of its purpose, while Landschaftspark Binntal lists tourism development as one park goal among others to aspire to. UNESCO Biosphäre Entlebuch stressed that all sectors are equally important for park collaboration. Nature and landscape were mentioned only once and added as an extra category by one park manager. This topic would have been chosen more often, however, if it had been listed as one of the potential sectors of collaboration.

\section{Regional embeddedness of parks}

Regional nature parks are supposed to contribute to sustainable regional development. A crucial prerequisite for this ambitious goal is what we call the regional embeddedness of the park. This idea is related, first, to the acceptance of the local population and businesses. Second, parks need to be institutionalized at regional level, carried by a regional association (see section above) and professionally managed by a regional agency. Conceptually, this argument draws from the literature on multi-level governance (Parra 2010) and spatial embeddedness (Hess 2004).

The survey results show that managing directors of Swiss regional nature parks rate the regional embeddedness of their park between 5 and 9 (mean 7) on a 1-10 scale, an assessment which was also shared by the two experts interviewed after the survey. Based on the survey results, six parks rate themselves between 5-6. 
These parks are criticized by actors for not being involved and lack a common acceptance among their inhabitants. The park development does not appear to be very dynamic. Eight parks hold a rating of 7-9, indicating better regional embeddedness. These parks benefit from strong networks, collaboration within the region, good publicity and support by the population. A variety of reasons influence the regional embeddedness of parks according to the survey of park managers:

- perception of the park as a controversial political issue;

- resistance or support from the public during the establishment of the park;

- exclusion or inclusion of stakeholders in different phases of park establishment and development;

- perception of the park as a new opportunity for the region, including access to financial resources;

- uncertainty about the impacts of the regional character of parks, including shifting decision making from municipalities to regional bodies;

presence and visibility of parks;

- complexity of the park's organization might lead to misunderstandings and scepticism;

- size of park in terms of area and number of municipalities or stakeholders involved;

- engagement: Parks offering activities and services for local population and visitors, focusing on different sectors and being open for collaboration;

- key individuals: Leadership and continuity in park management and board help to establish the park and to create park identity.

Regionally embedded parks can be characterized by this quote from one park manager: "Nobody fears the parks any longer. But the concept behind the parks, and what they are doing exactly, is not yet properly understood by the park inhabitants." According to another park manager one important reason behind rather weak regional embeddedness is the competition between the local and regional levels: "(...) the assessment would be improved, if the municipalities would realize that the nature park can belp to connect and unite different sectorial policies." In general, parks seem to be somewhat established as regional players and enjoy some sort of regional support. In some cases the exact function and purpose of regional nature parks is not clear or not accepted by everybody.

\section{Discussion}

This article sets out research questions to characterize the new governance of PAs in Switzerland by investigating regional nature parks. The new governance features - legislative framework, mandatory participatory park establishment, actor compositions, parks' understanding as a tool for regional development - are relevant to all parks. These new governance features can be understood as enabling conditions for effective governance as De Pourcq et al. (2015) put it in a study from Colombia. They identified building trust between partners and achieving more effective participation of local groups as important conditions to prevent and mitigate conflicts between parks and people. Knoepfel and Gerber (2008) explicitly show that regional nature parks provide appropriate governance mechanisms to integrate different goals and strategies of resource use and landscape development because they are not restricted by administrative boundaries.

We identified new governance structures evolving in relation to the pre-existing natural and socio-economic conditions of a region. This finding indicates that the bigger and more complex the structure of a park region, the more difficult it is for park management to integrate different levels, sectors, stakeholders and subregions, and establish a park identity. In Switzerland, parks with more complex governance structures include a rather high number of municipalities and cross cantonal boundaries (Gruyère Paysd'Enhaut, Doubs). These parks struggle more often than other parks with regional embeddedness because people's lack of interest or even rejection by some municipalities. In contrast, parks with clearer regional situations and forms of governance, e.g. Binntal, Diemtigtal and Thal, basically representing just one valley, are more deeply embedded regionally, and park inhabitants show greater identification with the park. Another example in that respect is the controversy around Biosfera Val Müstair. This controversy and issues of acceptance are at least in parts related to the specific geographic situation of Val Müstair as one of the few valleys in the Canton of Grisons located next to the Swiss National Park on the southern side of the Alps, while other parts of the UNESCO BR are part of the Engadin on the northern side of that mountain ridge, characterized by greater acceptance.

Other specific features not relevant to all parks have been revealed by looking at concrete governance practices. What is interesting in terms of the institutionalization of governance is, first, that the majority of parks follow the standard model of a park association, while a few are associated with a single municipality or a regional development agency. Second, park governance seems to be rather formalized, with clear responsibilities, statutes defining objectives, rules and bodies to implement these, and contracts between parks and FOEN as the main funder. On one hand, this proves the importance of legitimacy, accountability and, rather strongly, institutionalized structures for effective governance. In their review of protected area governance in 41 countries, Dearden et al. (2005) also found a greater use of formal accountability mechanisms. In addition to increased levels of participation, both features indicate improved PA governance in the course of the 1990s. On the other hand, these features are still flexible enough to enable regionally diverse governance forms and to support self-defined, regionally embedded and adapted development processes. This is exemplified by the parks' highly diversified funding portfolios, which differ considerably between parks and can 
be interpreted as a result of different funding strategies and the availability of different financial sources.

Also in line with these findings is the remarkable interplay between different public authority levels as well as the concurrence of top-down and bottom-up features of governance. The coordination of park matters seems to be most developed between the municipal and federal level, while the cantons are more in the background. This is remarkable because it empirically shows that concepts such as multi-level governance or the dichotomy of top-down and bottom-up are too schematic and too formal to grasp actual governance practices. Brenner and Job (2011), for instance, provided evidence from Mexican BRs that governance occurs simultaneously at global, national, regional and local levels.

It appears that the newly established regional nature parks complement, rather than substitute, older concepts of governance. The NCHA revision introduced new park categories, rules and incentives. As a result, regions have attracted new resources and increased the visibility of ecological issues and socioeconomic development. In what respect new regional nature parks in fact produce ecological and/or economic benefits has not been the objective of this study, though. Hirschi (2010) argues that park projects “(..) can provide a needed and therefore bighly welcome additional opportunity for rural areas to obtain new resources for both ecological and socio-economic improvements of their regions." The new legislative framework also transforms established decision-making routines by altering the actor composition and by integrating regional, non-governmental actors and municipal referenda. A ten-year planning horizon to implement the regional nature park's management plan allows for strategic development beyond short-term thinking. This leads to new ways of negotiating, agenda setting and consulting, and calls for better communication. Further, the new constellation of actors is increasingly horizontally organized, thus crossing sectoral and political-administrative borders. These findings confirm what Blom-Zandstra et al. (2016) identified as success factors in governing farmer-managed public goods: a mix of governance forms; visionary leadership with networks in both the public and the private sectors, and time for new ideas to mature and to build commitment among the actors.

\section{Conclusion}

This paper shows that Switzerland's regional nature parks are subject to a variety of different, sectoral and cross-sectoral targets at different levels. Fostering strategies to intensify biodiversity conservation and regional economic development simultaneously, among other goals, challenges the governance of PAs. It appears that parks with rather complex governance structures should allocate sufficient capacities and resources to the development of a sound regional network, such as holding regular and frequent meetings, formalizing decision-making processes and securing liability of participating actors. Also, there seems to be a limit to the spatial extension and number of participating actors for a park. Swiss regional nature parks come in sizes between the prescribed minimum area of $100 \mathrm{~km}^{2}$ and around $550 \mathrm{~km}^{2}$, and include between 1 and around 30 municipalities. These findings support Lockwood's (2010) proposal for assessments of the quality and effectiveness of protected area governance.

In order to strengthen the regional embeddedness and visibility of the parks, their relationships with different sectors and industries should be maintained and continuously extended. The results indicate that parks which establish broad projects and manage to integrate different actors, interests and a wide selection of topics are more embedded in a region. This finding can also be observed in other regional development programmes implemented by projects such as European Territorial Cooperation, better known as EU Interreg (Zäch \& Pütz 2014). In that respect, the UNESCO Biosphäre Entlebuch represents a good practice example which manages to equally incorporate actors from different sectors, such as mobility, culture, education, agriculture, economics, labelling, forestry, science and regional planning. The high reputation and appreciation of the UNESCO Biosphäre Entlebuch by the general public and regional economy can be attributed to a long tradition of cooperation and available financial resources. Both the park's self- and external assessments reveal a high regional embeddedness. In contrast, parks that restrict their collaboration to a smaller circle of actors reach fewer people and are thus less well known and less noticed. Highly crosslinked parks seem to raise regional awareness better and create a positive permanent impression on the inhabitants of a region. This could possibly increase regional acceptance of the parks and strengthen their role as independent regional players.

Particular attention has to be paid to the role of continuity in establishing long-term and stable governance structures. If parks fail to ensure continuous management structures and face frequent fluctuations, they are prone to blockades and delays in development. Instead of sharpening their role as a regional player, they are consumed by internal friction. Thus long-term support with sufficient financial and personnel resources, as well as knowledge transfer and consultation, should be provided by different political levels to ensure continuity in park management.

In order to better understand the governance of PAs, further research should focus on five issues. First, scale and power issues need to be studied in more detail and comparatively to better understand path dependencies, and the formation and establishment stage of parks (Pütz 2011). Second, leadership needs deeper analysis in two ways (Valente et al. 2015). On one hand, the role of different key actors during different phases of a park, such as preparation, es- 
tablishment and long-term implementation, has to be considered further. On the other hand, the park's leadership potential to shape regional development and to coordinate and represent regional interests against other political interests needs further investigation. Third, a deeper understanding of the different forms of participation and their impacts on park activities is needed to understand the potential of participation processes. Fourth, further research should concentrate on how regional embeddedness is connected with a park's potential to set and achieve its goals. Regional nature parks, in particular, raise the old open question of how PAs can balance the different goals of conservation and regional economic development. Fifth, further governance analyses should take up and further develop the IUCN Protected Area Matrix - a classification system for PAs that includes both management category and governance type (Borrini-Feyerabend et al. 2013, 44). Related research seems to be promising as the practice of PA governance shows that some PAs combine features of several governance types, and governance arrangements often change over time.

\section{References}

Armitage, D., R. de Loë, R. Plummer 2012. Environmental governance and its implications for conservation practice. Conservation Letters 5: 245-255.

Arts, B., J. Behagel, E. Turnhout, J. de Koning \& S. van Bommel 2014. A practice based approach to forest governance. Forest Policy and Economics 49: 4-11.

Austin, R., N. Thompson \& G. Garrod 2016. Understanding the factors underlying partnership working: A case study of Northumberland National Park, England. Land Use Policy 50: 115-124.

BAFU Bundesamt für Umwelt (Hrsg.) 2013. Pärke von nationaler Bedeutung: Produktelabel. Richtlinie zur Verleihung und Verwendung des Produktelabels. Stand April 2013. Umwelt-Vollzug Nr. 0924. Bundesamt für Umwelt, Bern. [In German]

BAFU Bundesamt für Umwelt 2015a. Pärke von nationaler Bedeutung. Available at: http://www.bafu. admin.ch/landschaft/14534/15821/15839/index. htmllang=de (accessed 08/03/2016) [In German]

BAFU Bundesamt für Umwelt 2015b. Faktenblatt. Kantone erhalten 67.9 Millionen Franken für die Pärke von nationaler Bedeutung. Bundesamt für Umwelt, Bern. [In German]

Basurto, X. 2013. Linking multi-level governance to local common-pool resource theory using fuzzy-set qualitative comparative analysis: Insights from twenty years of biodiversity conservation in Costa Rica. Global Environmental Change 23: 573-587.

Beunen, R. \& K. van Assche 2013. Contested delineations: planning, law, and the governance of protected areas. Environment and Planning A 45: 1285-1301.

Blom-Zandstraa, M., H. Korevaara, M. Stuiverb \& A. Groot 2016. Critical success factors for governing farmer-managed public goods in rural areas in the
Netherlands. International Journal of Agricultural Sustainability 14(1): 45-64.

Borrini-Feyerabend, G., N. Dudley, T. Jaeger, B. Lassen, N. Pathak Broome, A. Phillips \& T. Sandwith 2013. Governance of Protected Areas: From understanding to action. Best Practice Protected Area Guidelines Series No. 20, Gland, Switzerland: IUCN.

Brenner, L. \& H. Job 2011. Challenges to actororiented environmental governance. Examples from three Mexican biosphere reserves. Tijdschrift voor economische en sociale geografie (103)1: 1-19.

Buono, F., K. Pediaditi \& G.J. Carsjens 2012. Local Community Participation in Italian National Parks Management: Theory versus Practice. Journal of Environmental Policy \& Planning 14: 189-208.

De Pourcq K., E. Thomas, B. Arts, A. Vranckx, T. Léon-Sicard \& P. Van Damme 2015. Conflict in Protected Areas: Who Says Co-Management Does Not Work? PLoS ONE 10(12): e0144943.

Dearden, P., M. Bennett \& J. Johnston 2005. Trends in global protected area governance 1992-2002. Environmental Management 36(1): 89-10.

Eagles, P.F.J. 2009. Governance of recreation and tourism partnerships in parks and protected areas. Journal of Sustainable Tourism 17(2): 231-248.

Eagles, P.F.J. 2014. Research priorities in park tourism. Journal of Sustainable Tourism 22(4): 528-549.

Gerber, J.-D. \& P. Knoepfel 2008. Towards integrated governance of landscape development: The swiss model of regional nature parks. Mountain Research and Development 28(2): 110-115.

Hammer, T., Mose, I., Siegrist, D., \& N. Weixlbaumer (eds.) 2016. Parks of the Future. Protected Areas in Europe Challenging Regional and Global Change. München.

Hammer, T. \& D. Siegrist 2016. Regional change management and collaborative regional governance as approaches tackling regional and global change in parks? Lessons learned from the Swiss model of parks of national significance. In: Hammer, T., Mose, I., Siegrist, D., \& N. Weixlbaumer (eds.), Parks of the Future. Protected Areas in Europe Challenging Regional and Global Change. München. 85-100.

Hess, M. 2004. 'Spatial' relationships? 'Towards a reconceptualization of embeddedness. Progress in $\mathrm{Hu}$ man Geography 28: 165-186.

Hirschi, C. 2010. Strengthening Regional Cohesion: Collaborative Networks and Sustainable Development in Swiss Rural Areas. Ecology and Society 15(4): 16.

Holmes, G. 2013. Exploring the Relationship Between Local Support and the Success of Protected Areas. Conservation and Society 11: 72-82.

Lockwood, M. 2010. Good governance for terrestrial protected areas: a framework, principles and performance outcomes. Journal of Environmental Management 91(3): 754-766.

Ly, T.P. \& H. Xiao 2016. An innovative model of park governance: evidence from Vietnam. Journal of Ecotourism 15: 99-121. 
Mose, I. \& N. Weixlbaumer 2006. Protected Areas as a Tool for Regional Development? In: Siegrist, D., C. Clivaz, M. Hunziker \& S. Iten (eds.), Exploring the Nature of Management. Proceedings of the Third International Conference on Monitoring and Management of Visitor Flows in Recreational and Protected Areas. University of Applied Sciences Rapperswil, Switzerland, 13-17 September 2006. Rapperswil. 149-154.

Novellie, P., H. Biggs \& D. Roux 2016. National laws and policies can enable or confound adaptive governance: Examples from South African national parks. Environmental Science \& Policy 66: 40-46.

Parra, C. 2010. Sustainability and multi-level governance of territories classified as protected areas in France: the Morvan regional park case. Journal of Environmental Planning and Management 53(4): 491-509.

Premauer J.M. \& F. Berkes 2015. A pluralistic approach to protected area governance: Indigenous peoples and Makuira National Park, Colombia. Ethnobiology and Conservation 4: 1-16.

Pütz, M. 2011. Power, scale and Ikea: analysing urban sprawl and land use planning in the metropolitan region of Munich, Germany. Regional Environmental Governance: Interdisciplinary Perspectives, Theoretical Issues, Comparative Designs (REGov). Procedia Social and Behavioral Sciences 14: 177-185.

Pütz, M. \& H. Job 2016. Governance und Regionalentwicklung in Großschutzgebieten der Schweiz und Österreichs. Raumforschung und Raumordnung 74(6): 569-583. DOI 10.1007/s13147-016-0451-2.

Robinson, L.W. \& E. Makupa 2015. Using Analysis of Governance to Unpack Community-Based Conservation: A Case Study from Tanzania. Environmental Management 56: 1214-1227.

Schweizerischer Bundesrat 2007. Verordnung über die Pärke von nationaler Bedeutung (Pärkeverordnung, PäV) vom 7. November 2007. Available at: https://www.admin.ch/opc/de/officialcompilation/2007/5241.pdf [In German]

Valente, F., D. Dredge \& G. Lohmann 2015. Leadership and governance in regional tourism. Journal of Destination Marketing \& Management 4: 127-136.
Wallner, A. 2012. Thematic catalogue of research topics on Swiss parks. eco.mont 4(2): 37-40.

Weissen, A. 2009. The park creation boom in Switzerland. eco.mont 1(2): 67-68.

Zäch, C. \& M. Pütz 2014. Regional Governance in der grenzüberschreitenden Regionalentwicklung. Eine Analyse des INTERREG-Programms AlpenrheinBodensee-Hochrhein. disP - The Planning Review 50(4): 29-42.

\section{Authors}

Marco Pütz ${ }^{1}$

Dr. oec. publ, Dipl-Geogr., is head of the research group Regional Economics and Develpment at the Swiss Federal Institute for Forest, Snow and Landscape Research WSL. His research interests are environmental governance, regional governance, spatial planning, adaptation to climate change as well as urban and regional economics. E-mail: marco.puetz@wsl.ch

\section{Lena Gubler}

is a researcher at the Swiss Federal Institute for Forest Snow and Landscape Research WSL. She studied geography and modern history at the University of Bern, Switzerland. Her research interests include regional development and governance, as well as the conservation of moors and mechanisms for $\mathrm{CO}_{2}-$ compensation. E-mail: lena.gubler@wsl.ch

\section{Yasmine Willi ${ }^{1}$}

is an economic geographer and $\mathrm{PhD}$ candidate at the Swiss Federal Institute for Forest Snow and Landscape Research WSL. In her research project she analyses the governance of regional development using the examples of regional nature parks and the new regional policy in Switzerland. E-mail: yasmine.willi@ wsl.ch

${ }^{1}$ Swiss Federal Institute for Forest, Snow and Landscape Research WSL, Economics and Social Sciences, Zürcherstrasse 111, 9003 Birmensdorf, Switzerland. 